\title{
NOBEL PRIZE WINNER ERWIN SCHRÖDINGER: THE PHYSICIST, PHILOSOPHER, AND GODFATHER OF MOLECULAR BIOLOGY AND GENETICS
}

\author{
T. V. DANYLOVA' ${ }^{1}$ S. V. KOMISARENKO \\ ${ }^{1}$ National University of Life and Environmental Sciences of Ukraine, Kyiv; \\ e-mail: danilova_tv@ukr.net; \\ ${ }^{2}$ Palladin Institute of Biochemistry, National Academy of Sciences of Ukraine, Kyiv; \\ e-mail:svk@biochem.kiev.ua
}

Received: 11 March 2020; Accepted: 15 May 2020

The brilliant book "What is Life? The Physical Aspect of the Living Cell" authored by the prominent Nobel Prize-winning Austrian physicist Erwin Schrödinger became a successful attempt to bridge the gap between physics and biology. The philosophical thought of one of the founders of quantum mechanics inspired him to look closer at the enigma of life through the lens of quantum physics. A prominent physicist was focused on the thermodynamics of the living organisms and the nature of heredity. Schrödinger introduced the concept and notion of "negative entropy", suggested the idea of a genetic code and argued that the genetic material had to have a non-repetitive molecular structure. He considered a molecule as a solid-aperiodic crystal that forms the hereditary substance. Despite the fact that his book provoked different interpretations and his ideas were modified by later scientific development, it was Schrödinger who paved the way for the future research of genes: his book inspired the next generation of scientists to look for a secret life code, which was eventually found. His outstanding writing is still one of the most profound introductions into the subject and raises new questions. Schrödinger's genius reshapes our view on the nature and essence of life creating a launching pad for the new transdisciplinary paradigm, which can contribute to the development of a unified theory of everything in the spirit of Schrödinger's philosophy.

Ke y wo rd s: Erwin Schrödinger, Schrödinger equation, Schrödinger's cat paradox, quantum theory, negative entropy, code-script.

$\mathrm{N}$ owadays, the scientific community is increasingly aware of the need to have a comprehensive approach to the development of a new scientific paradigm of life. An exploration of living matter is actually at the mercy of life sciences, however, living organisms as a special form of matter could be understood deeper within the frame of a multidisciplinary approach to these objects [2-4]. This idea is not new. At all times, representatives of various scientific disciplines have tried to comprehend and interpret the phenomenon of life. They would like to exclaim as Flaubert's St. Anthony: "O joy! O bliss! I have beheld the birth of life! I have seen the beginning of motion" [5]. For example, the ancient Greek philosopher Aristotle in the $4^{\text {th }}$ cen- tury BCE put forward the assumption that all living organisms are likely to have innate purposes and they are drawn towards them.

In the $17^{\text {th }}$ century, the teleological concept gave way to the mechanistic explanation of both the world as a whole and living organisms in this world. In Newton's universe, all its parts are subject to the universal laws without any innate predisposition or goal. The world is a kind of a cloak mechanism. This mechanistic explanation of living creatures found its completion in La Mettrie's "Man a Machine" [6]. And for many decades, scientists had lacked reliable knowledge on the transformation of inanimate matter into living matter.

(C) 2020 Danylova T. V., Komisarenko S. V. This is an open-access article distributed under the terms of the Creative Commons Attribution License, which permits unrestricted use, distribution, and reproduction in any medium, provided the original author and source are credited. 


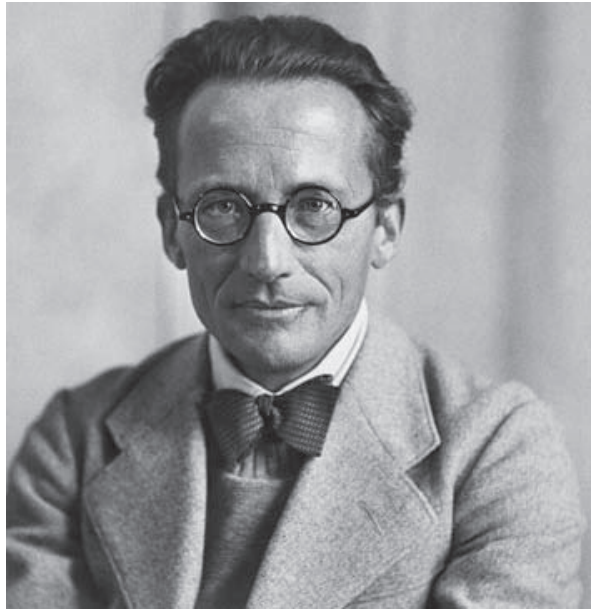

Erwin Schrödinger [1]

One of the attempts to bridge the gap between natural sciences and life sciences resulted in 1944 in the publication of the book "What is Life? The Physical Aspect of the Living Cell" authored by the prominent Nobel Prize-winning Austrian physicist Erwin Schrödinger (1887-1961).

Erwin Rudolf Josef Alexander Schrödinger was born on August 12, 1887, in Vienna, Austria. He was the only child of Rudolf Schrödinger, botanist and cerecloth producer, and Georgine "Georgie" Emilia Brenda Schrödinger (née Bauer) - daughter of Alexander Bauer, Rudolf's professor of chemistry in the Technical College of Vienna [7, 8].

Erwin's father was a Catholic, and his mother was a Lutheran. Despite the fact he grew up as a Lutheran, Erwin considered himself to be an atheist while showing a great interest in Eastern religions and pantheism: "I was born into an environment, I do not know where I came or whither I go or who I am... We try to discover what we can about the spatial and temporal context in which we were born, we were located. And in this effort, we find joy, we find it extremely interesting (even if not the purpose for which we are here?)" [9].

Until 11 years old, Erwin had a private education at home. In 1898, he entered Vienna's Akademisches Gymnasium, where he was a gifted student. His interests lay in physics, math, languages, and poetry [7]. He wrote later: "I was a good student in all subjects, loved mathematics and physics, but also the strict logic of the ancient grammars, hated only memorizing incidental dates and facts. Of the German poets, I loved especially the dramatists, but hated the pedantic dissection of their works" [10].

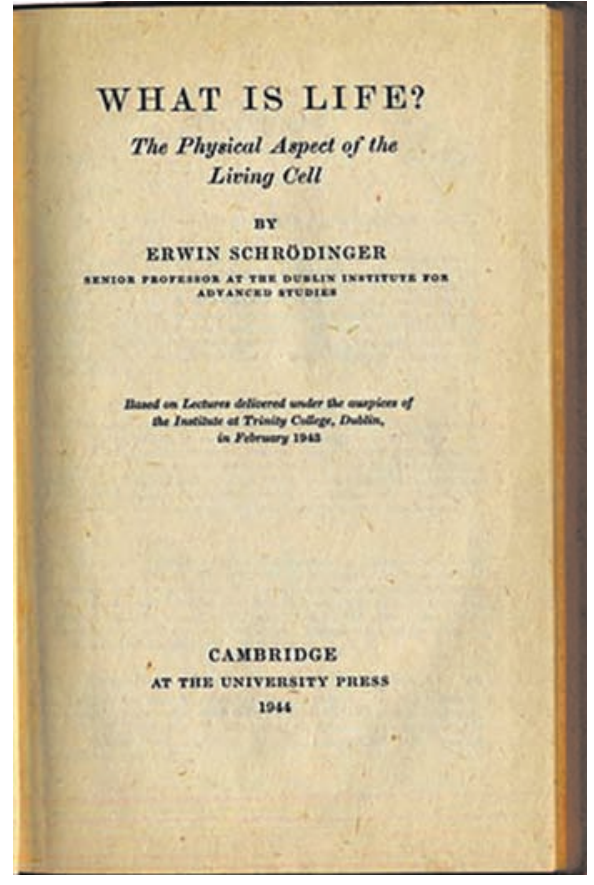

In 1906-1910, Erwin Schrödinger studied at the University of Vienna under F.S. Exner and F. Hasenöhrl, Boltzmann's successor, whose lectures on theoretical physics had a great impact on Schrödinger. A future Nobel Prize winner deeply studied analytical mechanics, application of partial differential equations to dynamics, eigenvalue problems, Maxwell's equations, electromagnetic theory, optics, thermodynamics and other. He also conducted experimental work with K.W.F. Kohlrausch [8]. Schrödinger acquired a mastery of eigenvalue problems in the physics of continuous media, which became the foundation for his future work. In 1910, Schrödinger received his doctorate in theoretical physics at the University of Vienna. His dissertation was titled "On the conduction of electricity on the surface of insulators in moist air” [12].

Since his young age, Erwin was influenced by A. Schopenhauer and his seminal work "The World as Will and Representation" [13] and became interested in philosophy and color theory.

Enthusiasm for Schopenhauer's philosophy was reflected in Schrödinger's lecture delivered at Trinity College in 1956: "When an archaeologist reconstructs a city or a culture long bygone, he is interested in human life in the past, in actions, sensations, thoughts, feelings, in joy and sorrow of humans, displayed there and then. But a world existing for many millions of years without any mind being aware of it, contemplating it, is it anything at all? 
Has it existed? For do not let us forget: to say, as we did, that the becoming of the world is reflected in a conscious mind is but a cliche, a phrase, a metaphor that has become familiar to us. The world is given but once. Nothing is reflected. The original and the mirror-image are identical. The world extended in space and time is but our representation (Vorstellung). Experience does not give us the slightest clue of its being anything besides that - as Berkeley was well aware” [14]. In 1911, Schrödinger became an assistant to Exner and conducted practical work for students.

During World War I, Ervin Schrödinger was drafted into military forces, where he served as an artillery officer. After World War I in 1920, he married Annemarie Bertel.

The same year he became an assistant to M. Wein at the Jena University, then obtained the position of extraordinary professor in Stuttgart, an ordinary professor in Breslau, and then he settled for six years at the University of Zurich. The intellectual atmosphere in Zürich inspired Schrödinger and he became engaged in a variety of subjects in theoretical physics. Here he dealt with specific heats of solids, problems of thermodynamics, atomic spectra, and physiological studies of colors [15].

Erwin Schrödinger explored the atomic structure and later - quantum statistics. The idea on the wave nature of electrons developed by the prominent French physicist L. de Broglie had a great impact on Schrödinger, and this became a turning point in the direction of his research. Very soon Schrödinger made his most important contribution to physics - wave equation that is now known as the Schrödinger equation. Schrödinger's theory described the behavior of the particles of matter that have a dual nature and in some situations act like waves. Schrödinger equation is a linear partial differential equation that predicts the future behavior of a dynamic system. As a wave equation in terms of the wave function, it "predicts analytically and precisely the probability of events or outcome" [16].

M. Planck described Schrödinger's contribution into physics as "epoch-making work", while A. Einstein said that "the idea of ... work springs from true genius" [10].

Schrödinger equation became the fundamental equation of quantum mechanics and contributed to the formation of the basis for Schrödinger's scientific research that resulted in his Nobel Prize in Physics. In 1933, the Nobel Prize in Physics was awarded jointly to Erwin Schrödinger and Paul Dirac "for the discovery of new productive forms of atomic theory" [19].

On December 10, 1933, Professor H. Pleijel, Chairman of the Nobel Committee for Physics of the Royal Swedish Academy of Sciences during the Presentation Speech stated: "Professor Schrödinger. Through a study of the wave properties of matter you have succeeded in establishing a new system of mechanics which also holds good for motion within the atoms and molecules. With the aid of this socalled wave mechanics you have found the solution to a number of problems in atomic physics. Your theory provides a simple and convenient method for the study of the properties of atoms and molecules under various external conditions and it has become a great aid to the development of physics” [20].

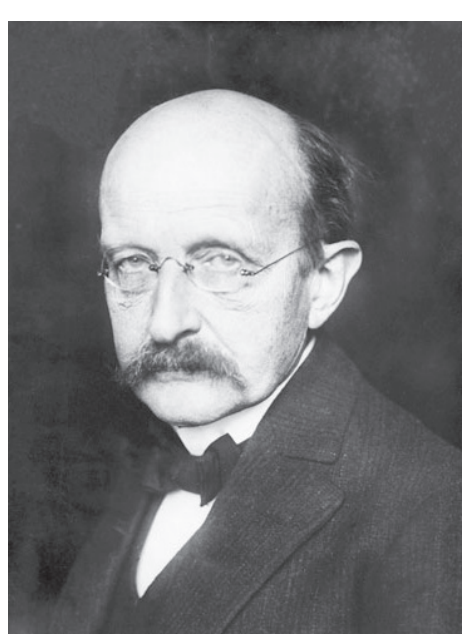

Max Planck [17]

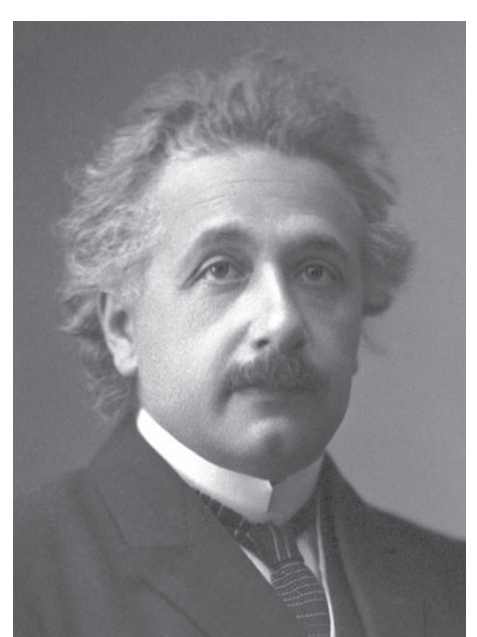

Albert Einstein [18] 
In 1927, Schrödinger left his position in Zurich and joined the Friedrich Wilhelm University in Berlin, where he became a colleague of A. Einstein. He was elected to the Berlin Academy of Sciences at the age of forty-two being the youngest member of it. Here he remained till 1933 when he decided he could not live in a country where Nazi's anti-Semitism became the rule of the political game. He moved to the United Kingdom becoming a Fellow of Magdalen College at the University of Oxford.

After an intense exchange of letters with Einstein in 1935, Schrödinger devised his famous thought experiment known as Schrödinger's cat: "A cat is in a box with a source of poison gas that would be triggered (or not) by the decay of one electron in one direction or another. Because of the uncertainty of the electron's behavior, there exists a moment in time when the observer is unsure whether the cat is alive or dead, and in some sense, it's both!" [7].

Schrödinger aimed to illustrate the problem of applying quantum theory to our daily life. "Schrödinger's cat" paradox gave rise to many physical, philosophical, and pseudo-scientific interpretations that in fact had little to do with Schrödinger's primary ideas to show the absurdity of the Copenhagen interpretation of quantum mechanics. Fortunately, no cat was harmed during a thought experiment [21].
In 1937, Schrödinger received the Max Planck Medal. He had traveled and worked in Austria, Belgium, the Pontifical Academy of Science in Rome until he got an invitation from Irish Prime Minister E. de Valera to work at the Institute for Advanced Studies in Dublin, Ireland, heading its School for Theoretical Physics. He became Director of the School for Theoretical Physics in 1940 and remained in Dublin until the mid-1950s. In 1949, Schrödinger was elected a Foreign Member of the Royal Society. In 1956, Schrödinger returned to Vienna, where he continued his career as professor emeritus at his Alma Mater [22]. The brilliant physicist Erwin Schrödinger died of tuberculosis on January 4, 1961, in his hometown of Vienna.

Erwin Schrödinger was unconventional both in his private life and in his search for knowledge and truth. He was distinguished by his extraordinary intellectual versatility. Trying to unite gravity, electromagnetism, and nuclear forces within the framework of General Relativity, Schrödinger worked on a Unified Field Theory, but being criticized by Einstein he gave up his work.

Schrödinger was deeply involved in philosophy and metaphysics. He summarized his study of the ancient Greek philosophy and science in his book "Nature and the Greeks" [23].

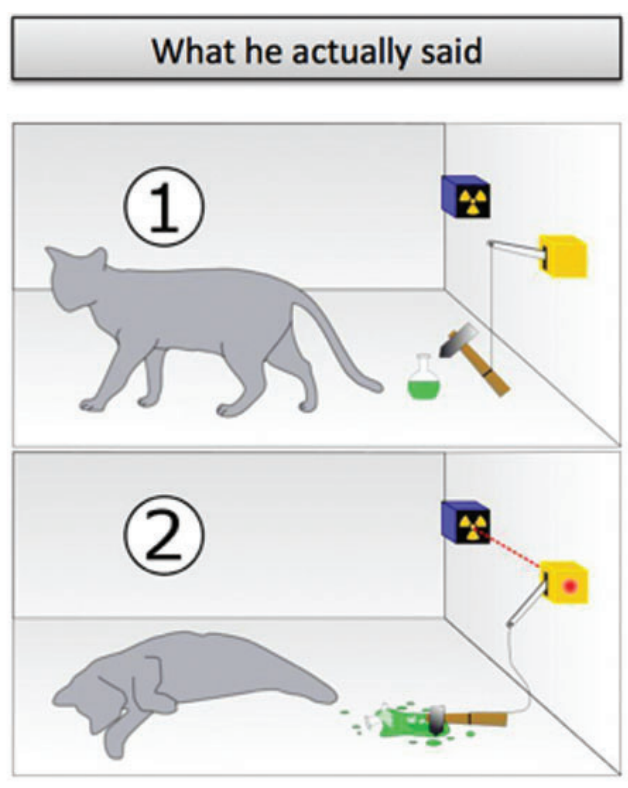

"That's absurd. It's one or the other."

"Cats can be both alive and dead!"

Schrödinger's cat [21] 
His life-long interest in the Vedanta philosophy reflected in his book "My View of the World", where he developed an idea on the possibility of an individual consciousness to be just a manifestation of a unitary consciousness [24].

Schrödinger put it in the following way: "Looking and thinking in that manner you may suddenly come to see, in a flash, the profound rightness of the basic conviction in Vedanta: it is not possible that this unity of knowledge, feeling and choice which you call your own should have sprung into being from nothingness at a given moment not so long ago; rather this knowledge, feeling and choice are essentially eternal and unchangeable and numerically one in all men, nay in all sensitive beings. But not in this sense - that you are a part, a piece, of an eternal, infinite being, an aspect or modification of it, as in Spinoza's pantheism. For we should then have the same baffling question: which part, which aspect are you? What, objectively, differentiates it from the others? No, but, inconceivable as it seems to ordinary reason, you - and all other conscious beings as such - are all in all. Hence this life of yours which you are living is not merely a piece of the entire existence, but is in a certain sense the whole; only this whole is not so constituted that it can be surveyed in one single glance. This, as we know, is what the Brahmins express in that sacred, mystic formula which is yet really so simple and so clear: Tat tvam asi, this is you. Or, again, in such words as ' $\mathrm{I}$ am in the east and in the west, I am below and above, I am this whole world"' [24].

Schrödinger's philosophical thought inspired him to look closer at the enigma of life through the lens of quantum physics, and eventually he 'invaded' the territory of life sciences that resulted in his book "What is Life? The Physical Aspect of the Living Cell" $[25,26]$

This famous book was based on Schrödinger's lectures conducted in Dublin in 1943. Physical concepts were transferred into biology that led to its progress. A prominent physicist was focused on the thermodynamics of the living organisms and the nature of heredity.

Schrödinger introduced the concept and notion of "negative entropy", which he explained as entropy, taken with the negative sign. As far as living organisms delay the decay into thermodynamical equilibrium, or maximum entropy, i.e., death, they continually draw "from its environment negative entropy - which is something very positive... What an organism feeds upon is negative entropy. Or, to put it less paradoxically, the essential thing in metabolism is that the organism succeeds in freeing itself from all the entropy it cannot help producing while alive" [25].

Explaining the processes that take place within a living organism in the space-time continuum, Schrödinger emphasized that functioning of an organism requires exact physical laws, the precision of which is based on a large number of interacting atoms. To be stable and capable of developing the orderly thought, an organism and all the processes within it must have "an extremely "manyatomic' structure and must be safeguarded against haphazard, 'single-atomic' events attaining too great importance” [25].

To a large extent, Schrödinger based his material on "Über die Natur der Genmutation und der Genstruktur" by N.W. Timoféeff-Ressovsky, K.G. Zimmer and M. Delbrück [27], who concluded that genes had an unknown chemical structure and a special locus on the chromosome, and they calculated about the size of a gene [28].

Looking at the phenomenon of life from the standpoint of physics, Schrödinger focused on immature at that time field of genetics. At that moment, most biologists considered that genes were likely to be proteins. Though Schrödinger mentioned that proteins were long-chain polymers, he was not aware of the paper of O. Avery, C. Macleod and M. McCarty [29] published in 1944 while his book was in press. This paper described the experiment that isolated DNA as the material of which genes and chromosomes are made.

Schrödinger put forward the idea that it should be a complex molecule, which keeps all the genetic information in a kind of code that determines the development and functioning of a living organism [30]. He presented a determinist vision of the role of genes. Describing the four-dimensional pattern (the structure and functioning of the organism as well as its ontogenetic development from the fertilized egg cell to the stage of maturity), Schrödinger stressed that it was well known at that time that this whole pattern is determined by the structure of one cell the fertilized egg, moreover, its nucleus, which in the resting state is seen as a network of chromatin. During mitosis and meiosis, it is seen to consist of a set of fiber-shaped or rod-liked particles named chromosomes that exist in two sets, which despite the difference in shape and size are alike. One set comes from the mother, the other - from the father. 
Schrödinger suggested that chromosomes contained the entire pattern of any individual's development in a kind of code-script, and every set of chromosomes contained the full code. "In calling the structure of the chromosome fibres a code-script we mean that the all-penetrating mind, once conceived by Laplace, to which every causal connection lay immediately open, could tell from their structure whether the egg would develop, under suitable conditions, into a black cock or into a speckled hen, into a fly or a maize plant, a rhododendron, a beetle, a mouse or a woman... But the term code-script is, of course, too narrow. The chromosome structures are at the same time instrumental in bringing about the development they foreshadow. They are law-code and executive power - or, to use another simile, they are architect's plan and builder's craft - in one" [25].

It was Schrödinger who suggested the idea of a genetic code and argued that the genetic material had to have a non-repetitive molecular structure. Considering a molecule as a solid - a crystal, Schrödinger claimed: "We believe a gene - or perhaps the whole chromosome fibre - to be an aperiodic solid" [25]. This aperiodic crystal forms the hereditary substance.

In the epilogue, Schrödinger philosophically interpreted his physical explanation of the biological problems. He developed the idea that the bodily space-time events together with the mind activity were statistically determined and quantum indeterminacy played no biologically relevant role, except perhaps by enhancing the purely accidental character in such events as meiosis, natural and X-ray-induced mutation, etc. Analyzing the concept of Ego/I, Schrödinger considered plurality of consciousness to be a manifestation of the different facets of One Consciousness, Universal Oneness.

Schrödinger's book "What is Life? The Physical Aspect of the Living Cell" with its metaphors that provoked different interpretations was met with both criticism and admiration [31, 32]. While a British geneticist, biometrician, psychologist J. B. S. Haldane reviewed Schrödinger's book favorably emphasizing that every geneticist would be interested in Schrödinger's approach, an American geneticist H. J. Muller harshly criticized Schrödinger's limited knowledge in genetics and especially his philosophical epilogue and an American biologist G. S. Stent pointed out that Schrödinger did not conduct experiments in genetics discussing it and made no attempts to include chemistry in his discussion [33].
However, "What is Life?” contained something more important than just the attempt to bridge the gap between physics and biology. Erwin Schrödinger paved the way for the future research of genes: his book inspired the next generation of scientists to look for a secret life code, which was eventually found.

Although much of what Erwin Schrödinger wrote in his book in 1944 has been modified by later development of science, his outstanding writing is still one of the most profound introductions into the subject and raises new questions. Schrödinger's deep interest in consciousness, mind, "orderly thought" and his original physical-philosophical worldview has influenced the development of transpersonal psychology and is becoming a source of inspiration for the neuroscience of the future. Schrödinger's genius reshapes our view on the nature and essence of life creating a launching pad for the new transdisciplinary paradigm [34, 35], which can contribute to the development of a unified theory of everything in the spirit of Schrödinger's philosophy.

\section{ЛАУРЕАТ НОБЕЛІВСЬКОЇ ПРЕМІЇ ЕРВІН ШРЕДІНГЕР: ФІЗИК, ФІЛОСОФ І ХРЕЩЕНИЙ БАТЬКО МОЛЕКУЛЯРНОЇ БІОЛОГІї ТА ГЕНЕТИКИ}

\section{T. В. Данилова ${ }^{1}$, С. В. Комісаренко ${ }^{2}$}

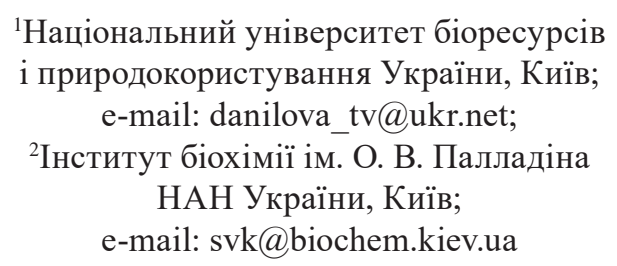

Блискуча книга «Що таке життя? Фізичний аспект живої клітини» відомого австрійського фізика - лауреата Нобелівської премії Ервіна Шредінгера стала вдалою спробою усунути розрив між фізикою та біологією. Філософська думка одного 3 основоположників квантової механіки надихнула його розглянути загадку життя крізь призму квантової фізики. Видатний фізик зосередився на термодинаміці живих організмів та природі спадковості. Шредінгер ввів поняття негативної ентропії, запропонував ідею генетичного коду і стверджував, що генетичний матеріал повинен мати неповторну молекулярну структуру. Він розглядав молекулу як тверде тіло - аперіодичний кристал, який 
утворює спадкову речовину. Незважаючи на те, що книга спричинила різні інтерпретації, а ідеї, викладені в ній, були відкориговані пізнішими науковими розробками, саме Шредінгер проклав шлях для майбутніх дослідників генів: його книга надихнула наступне покоління вчених віднайти секретний код життя. Його видатний твір і досі залишається одним із найглибших вступів до предмету і зумовлює нові питання. Геній Шредінгера змінює наш погляд на природу та сутність життя, створюючи стартовий майданчик для нової трансдисциплінарної парадигми, яка може сприяти розробці єдиної теорії всього в дусі філософії Шредінгера.

К л юч о в і с лов а: Ервін Шредінгер, рівняння Шредінгера, парадокс кота Шредінгера, квантова теорія, негативна ентропія, код-скрипт.

\section{References}

1. Ball P. Schrödinger's cat among biology's pigeons: 75 years of What is Life? Nature. 2018: 560(7720): 548-550.

2. VynogradovaRP, Danilova VM,KomisarenkoSV. The Nobel laureates contribution to the study of carbohydarte metabolism and its regulation. A. Harden, H. Euler-Chelpin, C. F. Cori, G. T. Cori, E. Sutherland, L.F. Leloir, H. Krebs, F. Lipmann, P. Mitchell. Ukr Biochem J. 2020: 92(1): 135-163.

3. Linus Pauling. X-ray crystallography and the nature of the chemical bond. Oregon State University's Special Collection, April 1991. Regime of access : http://scarc. library.oregonstate.edu/coll/pauling/bond/ notes/1991a3.3.html.

4. Danylova T, Komisarenko S. Born in Ukraine: Nobel Prize Winners Ilya Mechnikov, Selman Waksman, Roald Hoffmann and Georges Charpak. Ukr Biochem J. 2019: 91(3): 127-137.

5. Flaubert G. The Temptation of St. Anthony. 2016. Regime of access : http://www.gutenberg. org/files/52225/52225-h/52225-h.htm.

6. La Mettrie J.O. Man a Machine. Create Space Independent Publishing Platform, 2018. 278 p.

7. Ervin Schrödinger. Famous Scientists. The Art of Genius. Regime of access : https://www. famousscientists.org/erwin-schrodinger-2/

8. Ervin Schrödinger. People. Pill. Regime of access: https://peoplepill.com/people/erwinschroedinger/
9. Ervin Schrödinger. Astronoo. Regime of access : http://www.astronoo.com/en/biographies/erwinschrodinger.html.

10. Erwin Rudolf Josef Alexander Schrödinger. School of Mathematics and Statistics. University of St Andrews, Scotland. Regime of access : http://mathshistory.st-andrews.ac.uk/ Biographies/Schrodinger.html.

11. Erwin Schrödinger. 1887-1961. Regime of access : https://www.zbp.univie.ac.at/ schrodinger/euebersicht.htm.

12. Moore W. Schrödinger. Life and Thought. Cambridge University Press, 2015. 515 p.

13. Schopenhauer A. The World as Will and Representation. Vol. 1. Cambridge University Press, 2010. 696 p.

14. Schrödinger E. Mind and Matter. In: What is Life. The Physical Aspect of the Living Cell. Cambridge University Press, 1967. P. 91-164.

15. Ervin Schrödinger. Biographical. The Nobel Prize. Regime of access : https://www. nobelprize.org/prizes/physics/1933/schrodinger/ biographical/

16. Schrödinger equation. Regime of access : hyperphysics.phy-astr.gsu.edu/hbase/quantum/ schr.html.

17. Max Planck. Wikipedia. Regime of access : https://en.wikipedia.org/wiki/Max_Planck.

18. Albert Einstein - Biographical. Regime of access : https://www.nobelprize.org/prizes/ physics/1921/einstein/biographical/

19. The Nobel Prize in Physics 1933. Regime of access : https://www.nobelprize.org/prizes/ physics/1933/summary/

20. Award ceremony speech. Regime of access : https://www.nobelprize.org/prizes/physics/1933/ ceremony-speech/

21. Schrödinger's Cat Explained: The Most Simple Explanation Ever! Regime of access: https:// astronimate.com/article/schrodingers-catexplained/

22. Ervin Schrödinger. Biography. Regime of access: https://www.biography.com/scientist/ erwin-schrdinger

23. Schrödinger E. Nature and the Greeks. Canto: Cambridge University Press, 1954. 97 p.

24. Schrödinger E. My View of the World. Cambridge University Press, 2008. 81 p.

25. Schrödinger E. What is Life? The Physical Aspect of the Living Cell. Cambridge University Press, 1967. $184+$ viii p. 
26. Schrödinger, Erwin (1887-1961). Regime of access : https://hagstromerlibrary.ki.se/ books/16176

27. Timoféeff-Ressovsky N.W., Zimmer K.G., Delbrück M. Timoféeff-Ressovsky N.W., Zimmer K.G., Delbrück M. Über die Natur der Genmutation und der Genstruktur. In: Nachrichten von der Gesellschaft der Wissenschaften zu Göttingen. Berlin: Wiedmannsche Buchhandlung. 1935: 1(13): 189245.

28. Ganten D. What is Life? On Erwin Schrödinger, his cat, and the Journal of Molecular Medicine. J Mol Med. 2007: 85(12): 1291-1292.

29. Avery OT, Macleod CM, McCarty M. Studies on the Chemical Nature of the Substance Inducing Transformation of Pneumococcal Types. Induction of Transformation by a Deoxyribonucleic Acid Fraction Isolated from Pneumococcus Type III. J Exp Med. 1944: 79(2): 137-158.

30. Doménech F. Schrödinger, a Quantum behind the Secret of Life. Ventana al Comocimiento,
Open Mind, 2016. Regime of access : https:// www.bbvaopenmind.com/en/science/leadingfigures/schrodinger-a-quantum-behind-thesecret-of-life/

31. Margo CE, Harman LE. The Remarkable Life of Erwin Schrödinger's What is Life? The Pharos of Alpha Omega Alpha-Honor Medical Society. Alpha Omega Alpha. 2015: 78(4): 19-23.

32. Moberg C. Schrödinger's What Is Life?-The 75th Anniversary of a Book That Inspired Biology. Angew Chem Int Ed Engl. 2020; 59(7): 25502553.

33. Dronamraju KR. Erwin Schrödinger and the Origins of Molecular Biology. Genetics. 1999; 153(3): 1071-1076.

34. Danylova TV. Eastern Spiritual Traditions through the Lens of Modern Scientific Worldview. Anthropol Meas Philos Res. 2014; (5): 95-102.

35. Danylova TV. Eastern Mysticism and Timothy Leary: Human Beyond The Conventional Reality. Anthropol Meas Philos Res. 2017; (11): 135-142. 